pendix, der dokumenterer religiøst motiveret pres på ytrings- og religionsfriheden, og hvor der efter min vurdering er et lidt skævt fokus på islam. Hvis man læser Kristeligt Dagblad jævnligt vil man se, hvor mange også kristne anslag, der også er (hvoraf mange er med $i$ appendixet), og man vil se, at disse anslag ofte er ganske succesfulde $i$ at få lukket forestillinger, censureret forfattere etc. Der er et virkeligt og pågående pres imod frihedsrettighederne fra religionens og kulturens selvudnævinte talspersoner, og det er bogens styrke at bringe dette helt frem i debatten.

Som det fremgår af ovenstående er det en meget uhomogen bog, der måske nok vil for meget, $i$ den forstand at der ikke altid er tænkt nok over, hvordan de mange behandlede fænomener og sager hænger sammen, om de hænger sammen, om de er udtryk for én bagvedliggende problematik, eller hvad forholdet egentlig er. Bogen fremstår derfor ikke afklarende, hvis man går til den for at få en nøgle til at forstå de aktuelle udfordringer med hensyn til islam, kultur, ytringsfrihed, nationalisme, oplysning, integration m.m., som i debatten oftest blandes sammen i mere eller mindre uskønne blandinger. Her giver bogen ingen samlende forståelsesramme, hvilket synes at have været målet ved at tolke fænomenerne eller debatten om fænomenerne ind i kulturalismerammen. Til gengæld er bogen oplysende, provokerende og stimulerende, hvis man leder efter et indspark i debatten. Hvis man derimod ønsker at blive udfordret på sin egen position, så er dette bogen. For her meldes både kontant ud samtidig med at argumentationen føres på et højt og mestendels konsistent niveau. Hvis man ikke bare afviser projektet eller udfordringen, men tværtimod tager handsken op, så er der her både mange timer til læsning og endnu flere til eftertænksomhed.

Mikekel Thorup

\section{Metaphysik des Schwebens}

Vagn Andersen: Transformation Gottes - Abwandlungen des Begriffs des Unbedingten in der Moderne, Aarbus Universitetsforlag 2008, 324 sider, $398 \mathrm{kr}$.

En anmeldelse af denne disputats er en vanskelig sag. At der er vanskeligheder kan f.eks. gøres plausibelt ved henvisning til, at Vang Andersen selv har brugt 30 sider på at skrive et obligatorisk resume (på dansk). Jeg har aldrig før $i$ en disputats set så langt et resume, og det hører uden tvivl til de absolutte undtagelser. Det kunne have været interessant at se, hvad der var kommet ud af det, dersom V.A var blevet tvunget til at koge det ind til 3-5 siders normalpraksis.

Det lange resume har sikkert noget at gøre med flere forhold: for det første er argumentationen hele afhandlingen igennem på et uhyre højt niveau i stringens og problembevidsthed samtidig med at teori- 
landskabet er stort og bredt, hvortil kommer at tidshorisonten er betragtelig. Kort fortalt strækker det sig i tid ud fra Descartes til nutiden. Positionsfilosofisk omfatter det klassisk rationalistisk filosofi, tysk idealisme i bred forstand med vægten på Kant, Fichte og især Hegel, Kierkegaard, Gadamer, Heidegger og analytisk sprogfilosofi - det hele med Habermas som hovedperson og prisme. Et så stort felt kræver et fokus, for V.A. skriver ikke først og fremmest filosofihistorie. Ganske vist er der et fokus, nemlig Habermas' teori om den såkaldte eftermetafysiske tænkning især - men absolut ikke udelukkende - set i forhold til det ubetingede, Gud, det absolutte og totalitet. For det andet - og her drejer afhandlingen egentlig bort fra Habermas - opstår en helt ny problematik, da det går op for V.A. at Habermas, til trods for alle differentieringer og distinktioner samt en vag solidaritet med religion, egentlig ikke har ret meget - måske nok fornuftigt - men tillige ganske utilfredsstillende, at sige om religion og teologi. Den generelle postmetafysiske intersubjektivitetsteori, der på en og samme tid skal være base for opgøret med subjektivitetsfilosofien og grundlaget for modernitetsteorien er underlig usensibel i forhold til at stille noget op med religionens tilstedeværelse i det moderne. Hertil kommer en udpræget mangel på overhovedet at komme i kontakt med grænseerfaringer og religiøs erfaring. Habermas er nærmest religiøst tonedøv. Her er måske
- med Wittgensteins udtryk - ikke ligefrem tale om et "loss of problems", men til gengæld et massivt "loss of reality". Men værre: den religiøse og metafysiske flanke er, som det fint vises, noget som Habermas ikke uden vanskeligheder kan fornægte, al den stund hans egen konception hviler på en bekendelse til en humanitet, hvis potentiale dybest set må hentes fra en jødisk-kristen metafysisk og religiøs tradition. Tillige en tradition, der har kunnet sige noget $\mathrm{i}$ forhold til den subjektive erfaring, som Habermas også har vanskeligheder med at få plads til i sin intersubjektivitetsteori. Som det eksponeres overbevisende i Habermas`kritik af Rorty, bl.a. under påberåbelse af Putnam, kan en absolut eller total naturalistisk position ikke være gyldig: fornuften kan ikke uden selvamputeringer restløst naturaliseres. Også her trækkes der på ressourcer fra traditionen. Men i stedet for at anfægte Habermas ' modernitetsteori vil V.A. nu supplere den med en dimension, der retter op på denne manko. Det sker i form af en Kierkegaardlæsning, hvor K. Olesen Larsens Kierkegaardforståelse reaktualiseres. Det er for så vidt prisværdigt, men det betyder at fokus, der i forvejen var ret elastisk, glider et andet sted hen. Vi nærmer os her sandsynligvis spørgsmålet - som ikke stilles - om ikke denne supplering de facto åbner en flanke, der reelt dementerer dele af Habermas' modernitetsteori. Det opridsede kan være forklaringen på V.A.s meget omfattende resume. 
skyld Hannah Arendts. Når de kunne

Et centralbegreb - eller udtryk - går igen $\mathrm{i}$ afhandlingen, nemlig "Metaphysik des Schwebens", som V.A. har lånt og ladet sig inspirere af fra Walter Schultz. I afhandlingen bruges det $i$ en række forskellige sammenhænge, men helt overordnet refererer det til en tankeposition, der på en og samme tid afviser metafysik, samtidig med at den er afhængig af metafysik. Dette forhold er det en af afhandlingens store pointer og indsigter at have gjort klart - en afdækning, der er ganske interessant $i$ relation til en position, der betegner sig som postmetafysisk.

Men hvad er så egentlig metafysik i denne sammenhæng? Her er der faktisk en del uklarheder, for bestemmelsen dækker over et bredt spektrum fra en tænkning, der mener, at Gud(sbegrebet) er tilgængelig for filosofisk tilnærmen, over antagelsen af, at der findes noget ubetinget i og for tænkningen, noget ubetinget som hverken er underlagt historiens ændringer, menneskers konventioner, sprogpragmatiske regler eller naturens evolution, frem til en antagelse om, at filosofisk tænkning kan være autonom $i$ betydningen, at den ikke er henvist - so oder so - til videnskabelig erkendelse. Alt dette og meget mere benægtes i Habermas' udgave af den postmetafysiske tænkning. $\mathrm{Og}$ her følger V.A. ham.

Det kan undre, at f.eks. Løgstrups tænkning ikke bare som kontrastiv anfægtelse er berørt eller for den sags

bringes i spil skyldes bl.a., at de også har opdaget subjektfilosofiens problemer, men næppe kan siges restløst at have erstattet denne med en radikal intersubjektiv position. Og det har bl.a. betydning for metafysikproblematikken, som hos dem, for at sige det kort, både er mindre selvmodsigende og frem for alt i langt højere grad muliggør tænkning, der ikke behøver at blive tavs alt for hurtigt. I øvrigt også en tænkning, der ikke som Habermas' de facto overser den menneskelige spontanitet. Det kan også undre, at Habermas' påstand om, at autonom filosofi ikke længere er mulig i det moderne sådan uden videre tages for gode varer: "Gyldig tænkning eksister i moderniteten kun i kooperation med empirisk videnskab" (s.299). Her kunne man føle sig tvunget til at stille spørgsmålet: Was heisst Denken? Eller man kunne prøve at udlægge, hvad der ligger i ordet "kooperation". Det er nærliggende at antage, at det ville vise sig, at der her skjuler sig enten en banalitet eller et selvbeskadigende tankeforbud. Heldigvis er dette blot en programerklæring, som Habermas da heller ikke selv overholder.

\section{III}

Afhandlingen starter med en exorbitant dygtig rekonstruktion af den sene Habermas' tænkning fra Theorie des kommunikativen Handelns" til "Faktizität und Geltung, hvor der påvises vig- 
tige forskydninger ikke mindst i form af en afidealisering og en optagethed af den menneskelige endelighed og tidslighed. Fremstillingen slynger sig - med stort erkendelsesmæssigt afkast - ud og ind mellem Habermas, Hegel, Gadamer og Heidegger. Det er svært at forestille sig, at det kunne gøres mere overbevisende - når nu Habermas skal rekonstrueres og ikke kritiseres.

Afhandlingens reflekterende og ikke rekonstruerende højdepunkt indtræffer på siderne 189 til 202. På s. 189 hedder det sammenfattende: "Das Versprechen einer Teilhabe am Absoluten selbst, das noch mit dem starken Theoriebegriff der Metaphysik verbunden war, lässt sich auf nachmetaphysischen Bedingungen nicht wiederholen...Der starke Theoriebegriff der Metaphysik hatte noch..."kontakt mit dem Ausseralltäglichen" versprochen. Die Einlösung eines solchen Versprechens ist nach Habermas nicht mehr von der Philosophie zu erwarten“. Hos Habermas lyder det:"Nach der Metaphysik hat die Philosophische Theorie ihren ausseraltäglichen Status eingebüsst". (Nachmetaphysisches Denkens, Frankfurt am Main, 1988, s. 60).

Et problem her er, at størrelsen "ausseraltäglich" hos Habermas figurerer som en restbestand hans tankesystem egentlig ikke kan stille noget op med på anden vis end at relegere det til kunsten og religiøs praksis. Filosofisk er det lukket land. På højest forunderlig vis er Habermas nu plud- selig i sin modernitetsanalyse blevet førmoderne, nemlig i den forstand, at mens al førmoderne tænkning gik ud fra, at sandheden og normativiteten skulle søges i normaliteten, så ændrer dette sig radikalt fra moderniteten, nu bliver det sådan at sandhed og normativitet egentlig skal findes i ekstremerne. Habermas skal bestemt ikke kritiseres for at have undgået denne problematiske drejning og potensering af mistankens hermeneutik. Til gengæld kommer denne førmoderne position til at få ham til at underspille det "ausseraltägliches" blivende tilstedeværelse i det moderne. Habermas har aldrig haft blik for, at der er fænomener, som aldrig - uden beskadigelse - kan moderniseres, og dette sammen med hans holisme gør ham systematisk blind netop i forhold til fænomener som er "ausseraltägliche" - fænomener, der sikkert spiller - og altid har spillet - en helt konstitutiv rolle for den individuelle identitetsdannelse, hvad enten den så kaldes traditionel eller posttraditionel. V.A. er meget mild i sin omgang med Habermas' teori på dette punkt og nøjes med - efter at have presset alt det ud af Habermas' position, som lader sig gøre - at konkludere: "damit ist noch sehr wenig über die tieferen Problematik einer "Authentizität" des subjektiven Selbstverhältnis gesagt" (206). 
IV

Som oplysning skal det siges, at afhandlingen, som et sidetema ud fra K.Olesen Larsen inspireret Kierkegaardlæsning med samt overtagelse af Habermas almene modernitetsteori, også rummer overvejelser over teologiens skæbne i dag. Det er overvejelser, som der her ikke skal gås ind på. Blot skal det siges, at V.A. med sine bestemmelser vel sagtens helt afskaffer teologien.

Hans afhandling er imidlertid indleveret til, forsvaret ved og anerkendt af Det teologiske Fakultet ved Aarhus Universitet. Måske er dette også udtryk for en art "Schwebens".

Hvad der imidlertid ikke er noget svævende ved, er den kendsgerning, at vi her har at gøre med en disputats af en sjælden gennemarbejdet kvalitet og intellektuel styrke, som hæver den op på det allerhøjeste internationale niveau.

Hans Jorgen Schan\%

\section{Alain Badiou (2007): Grund- rids af metapolitikken.}

Alain Badiou: Grundrids af metapolitikken. Slagmarks Skyttegrausserie 2007, 250 sider, $168 \mathrm{kr}$.

Nogle malerier giver kun mening, når de ses på en vis afstand. Kommer vi for tæt på, opløses motivet i de enkelte penselstrøg, klatter, eller hvad motivets bestanddele nu består af, og billedet vil ikke længere give mening. Sådan er det til tider også med akademisk arbejde, og i hvert fald gælder det for Alain Badious Grundrids af metapolitikken. Det er der to grunde til. For det første er der reelt tale om en samling af artikler og boganmeldelser. For at finde en sammenhæng $i$ disse tekster kræver det, at man allerede har en vis afstand til stoffet. Grundrids af metapolitikken fungerer derfor dårligt som en introduktion til Badious værk og tænkning. For det andet er det ikke kun sammenhængen mellem de enkelte kapitler, der til tider kan være svær at finde. Også kapitlernes argumentation bærer præg af indforståethed og argumentationsspring. Stilen er typisk at fremsætte en række postulater, som sjældent underbygges tilfredsstillende.

For at sige det som det er, synes jeg ikke, at Grundrids af metapolitikken er en god bog - og det både af stilistiske og substantielle årsager. Ud over hvad der allerede er nævnt om det stilistiske, kan man nævne, at Badiou ikke er en filosof, som, når han går i dialog med en anden tænker, læser værket, kommentarlitteraturen og andet relevant materiale og grundigt og slidsomt arbejder sig frem mod og understøtter sine pointer. Hvis man ser det ikke at skrive sig ind i en tradition og bekende arv og gxld som noget særligt fransk, ja så er Grundrids af metapolitikken en meget fransk bog. Hvor andre franske filosoffer som f.eks. Deleuze, Derrida 